\title{
Pengaruh Kecukupan Modal pada Profitabilitas Dengan Good Corporate Goveranance Sebagai Variabel Pemoderasi
}

\author{
Ida Ayu Bintang Gesaputri ${ }^{1}$ \\ A. A. G. P.Widanaputra ${ }^{2}$ \\ ${ }^{1,2}$ Fakultas Ekonomi dan Bisnis Universitas Udayana (Unud), Bali, Indonesia \\ e-mail: bintang.gesa9g@gmail.com
}

\begin{abstract}
ABSTRAK
Penelitian ini bertujuan untuk mendapatkan bukti empiris mengenai pengaruh kecukupan modal pada profitabilitas dengan good corporate governance sebagai variabel pemoderasi. Penelitian ini dilakukan pada perusahaan perbankan yang terdaftar di Bursa Efek Indonesia tahun 2011-2016. Metode penentuan sampel yang digunakan adalah purposive sampling. Jumlah sampel yang diperoleh yaitu 42 observasian. Teknik Analisis data yang digunakan yaitu uji Moderated Regression Analysis (MRA). Berdasarkan hasil penelitian, diketahui bahwa good corporate governance bukan sebagai pemoderasi pengaruh kecukupan modal pada profitabilitas. Berdasarkan jangka waktu penerapan good corporate governance lebih bersifat jangka panjang sehingga tidak dapat diukur kesuksesannya berdasarkan profitabilitas yang bersifat jangka pendek. Implikasi teoretis penelitian adalah sebagai tambahan referensi penelitian selanjutnya mengenai penelitian yang berkaitan dengan teori struktur modal dan teori keagenan. Disisi lain implikasi praktis penelitian adalah sebagai tambahan informasi bagi investor sebelum melakukan investasi.
\end{abstract}

Kata Kunci : profitabilitas, kecukupan modal, dan good corporate governance

\section{ABSTRACT}

This study aims to obtain empirical evidence about the effect of capital adequacy on profitability with good corporate governance as a moderating variable. This research was conducted at banking companies listed on the Indonesia Stock Exchange in 2011-2016. The method of determining the sample used is purposive sampling. The data analysis technique used is the Moderated Regression Analysis (MRA) test. Based on the results of the study, it is known that good corporate governance is not as a moderating influence of capital adequacy on profitability. Based on the period of application of good corporate governance, it is more long-term so that success cannot be measured based on short-term profitability. The theoretical implications of research are in addition to references to further research regarding research related to capital structure theory and agency theory. On the other hand the practical implications of research are as additional information for investors before investing.

Keywords: profitability, capital adequacy, and good corporate governance

\section{PENDAHULUAN}

Bank dikenal sebagai lembaga keuangan yang kegiatan utamanya menerima simpanan giro, tabungan, dan deposit (Muchtar dkk, 2016:120). Kemudian bank juga dikenal sebagai tempat untuk meminjam uang (kredit). Perbankan memiliki peran yang sangat penting dalam mencapai tujuan nasional yang berkaitan dalam 
Ida Ayu Bintang Gesaputri dan A.A.G.P. Widanaputra. Pengaruh...

pemerataan dan peningkatan taraf hidup masyarakat serta menunjang berjalannya roda perekonomian. Mengingat fungsinya sebagai alat tranmisi kebijakan moneter, lembaga intermediasi, serta penyelenggara transaksi pembayaran, maka bank dipaksa untuk menerapkan sistem penilaian tingkat kesehatan bank, sehingga menjadi lebih kompetitif. Selain itu, karena bank sebagai industri yang mengandalkan kepercayaan masyarakat dalam kegiatan usahanya kinerja dan kesehatan bank perlu dijaga (Wangi dan Ramantha, 2017).

Bank dalam kegiatan operasionalnya memiliki tujuan utama yaitu dapat mencapai tingkat profitabilitas yang maksimal. Profitabilitas memliki arti penting dalam mempertahankan kelangsungan usaha dalam jangka panjang, karena profitabilitas menunjukan apakah badan usaha tersebut mempunyai prospek yang baik di masa yang akan datang. Bank juga akan harus berusaha menjaga profitabilitas tetap stabil bahkan meningkat agar dapat memenuhi kewajiban kepada stakeholder, meningkatkan daya tarik investor dalam menanamkan modal serta meningkatkan kepercayaan masyarakat agar menyimpan kelebihan dana yang dimiliki pada bank (Agustiningrum, 2013).

Tabel 1.

Laba Bersih Bank Umum Periode 2011-2016

\begin{tabular}{ccc}
\hline No & Tahun & Laba (Miliar Rupiah) \\
\hline 1 & 2011 & 75.077 \\
2 & 2012 & 92.830 \\
3 & 2013 & 106.707 \\
4 & 2014 & 112.160 \\
5 & 2015 & 104.628 \\
6 & 2016 & 106.544 \\
\hline
\end{tabular}

Sumber: Statistik Perbankan Indonesia, 2018

Pada tabel 1 menunjukan bahwa laba bersih pada bank umum pada peride 2011-2016 mengalami fluktuasi. Laba bersih terendah diperoleh pada tahun 2011 yaitu 75.077 miliar rupiah dan laba bersih tertinggi pada tahun 2014 yaitu 112.160 
miliar rupiah. Hal ini menunjukan bahwa laba bersih yang diperoleh bank umum cendrung belum stabil.

Salah satu rasio keuangan bank yang diunakan untuk mengukur dan membandingkan profitabilitas bank adalah rasio Net Interest Margin (NIM). NIM adalah rasio pendapatan bunga bersih (Raharjo et al., 2014). Menurut Riyadi (2006:21) NIM merupakan perbandingan persentase hasil bunga bersih terhadap total earning assets, sehingga diperoleh seberapa keuntungan bersih yang diperoleh bank dari aktivitasnya sebagai lembaga intermediasi. Dumicic dan Ridzak (2013) mengumukakan bahwa NIM merupakan salah satu indikator yang paling baik dan paling sering digunakan dalam menentukan biaya dan efisiensi dari aktivitas intermediasi keuangan yang dilakukan oleh bank. NIM diatur oleh bank untuk menutupi semua resiko dan biaya intermediasi (Marinkovic dan Radovic, 2014).

NIM digunakan sebagai alat ukur profitabilitas dalam penelitian ini karena NIM menunjukan kemampuan bank dalam menghasilkan keuntungan berupa pendapatan bunga, mengingat pendapatan bunga merupakan pendapat pokok bagi bank sebagai lembaga intermediasi, sehingga dengan memperhitungkan NIM akan terlihat seberapa pendapatan bunga bersih yang dapat dihasilkan bank dari usahanya mengelola aktiva produktifnya.

Tabel 2.

Perkembangan NIM pada Bank Umum Tahun 2011-2016

\begin{tabular}{ccccccc}
\hline \multirow{2}{*}{ Variabel } & $\mathbf{2 0 1 1}$ & $\mathbf{2 0 1 2}$ & $\mathbf{2 0 1 3}$ & $\mathbf{2 0 1 4}$ & $\mathbf{2 0 1 5}$ & $\mathbf{2 0 1 6}$ \\
\hline NIM (\%) & 5,91 & 5,49 & 4,89 & 4,23 & 5,39 & 5,63 \\
\hline Sumbr: Statistik
\end{tabular}


Ida Ayu Bintang Gesaputri dan A.A.G.P. Widanaputra. Pengaruh...

Berdasarkan tabel 2 diatas dapat dilihat juga bahwa rasio NIM mengalami fluktuasi pada tahun 2011-2016. Pada tahun 2011-2014 rasio NIM mengalami penurunan sedangkan pada tahun 2015-2016 mengalami peningkatan. Perkembangan NIM pada periode 2011-2016 memiliki rata-rata sebesar 5,26. Hasil ini masih belum menjadi harapan pemerintah melalui Otoritas Jasa Keuangan (OJK), karena dari pihak OJK memiliki rencana kebjikan mengenai penurunan margin bunga bersih atau NIM untuk meningkatkan efisiensi seiring dengan pemberlakukan Masyarakat Ekonomi ASEAN (MEA). Akibat dari penurunan margin keuntungan ini diharapkan juga bunga kredit turun dan memacu penyaluran kredit. Menurut Ketua Dewan Komisioner OJK Muliaman D.Hadad menjelaskan, OJK sempat menetapkan NIM pada bank umum sebesar $4 \%$ dan tengah membuat peraturan pemberian insentif bagi bank yang bersedia menurunkan NIM dan penetapan NIM (www.katadata.co.id).

Faktor penting agar suatu perusahaan dapat beroperasi adalah kecukupan modal. Bank dalam menyalurkan kredit kepada masyarakat juga memerlukan modal. Modal bank harus dapat juga digunakan untuk menjaga kemungkinan timbulnya risiko, diantarannya risiko yang timbul dari kredit itu sendiri. Bank perlu menyediakan penyediaan modal minimum untuk menanggulangi kemungkinana risiko yang terjadi. Bank Indonesia menetapkan Capital Adequacy Ratio (CAR) yaitu kewajiban penyediaan modal minimum yang harus selalu dipertahankan oleh setiap bank sebagai suatu proporsi tertentu dari total Aktiva Tertimbang Menurut Risiko (ATMR). Berdasarkan Peraturan No. 14/18/PBI/2012 mengenai permodalan dalam perusahaan yang diatur oleh Bank Indonesia 
menyebutkan bahwa rasio kewajiban penyediaan modal minimum yaitu minimal 8 persen.

Kecukupan modal dapat mencerminkan kemampuan perusahaan untuk mengawasi serta mengontrol risiko yang terjadi, yang bisa memengaruhi besarnya modal bank. Bank apabila mempunyai modal yang memadai maka dapat melakukan kegiatan operasionalnya dengan efisien, dan akan memberikan keuntungan pada bank tersebut (Anggreni dan Suardhika, 2014). Capital Adequacy Ratio (CAR) atau disebut rasio kecukupan modal, yaitu modal sebuah bank yang diperoleh dari dana sendiri (Luthfyanti, 2017). Modal disini berfungsi sebagai penyangga untuk menyerap berbagai macam kerugian yang ditimbulkan oleh risiko.

Terkait dengan kecukupan modal yang diproksikan dengan CAR, hasil penelitian Rahim, (2014), Margaret dkk., (2014) menunjukan bahwa CAR mempengaruhi NIM secara signifikan. Hasil penelitian lain yang dilakukan oleh McShane and Sharpe (1985), Brock and Suarez (2000), Raharjo et al., (2014), Nasserinia (2015), Leykun (2016) menunjukkan bahwa CAR berpengaruh positif terhadap NIM. Akan tetapi bukti empiris lain menunjukan tidak selamanya CAR mempunyai pengaruh positif terhadap profitabilitas. Hasil penelitian Norris and Norris (2007), Ariff and Skully (2008), Dumicic and Tomislav (2012) menunjukkan hasil yang berbeda, dimana CAR berpengaruh negatif terhadap NIM.

Ketidakkonsistenan hasil penelitian tersebut yang melatarbelakangi penelitian ini untuk terus dilanjutkan. Perbedaan hasil dari penelitian sebelumnya 
Ida Ayu Bintang Gesaputri dan A.A.G.P. Widanaputra. Pengaruh...

bias dipecahkan dengan menggunakan pendekatan kontigensi (contingency approach) (Govindarajan, 1986). Hal ini dilakukan dengan memasukkan variabel lain yang mungkin mempengaruhi kecupukan modal denga profitabilitas. Variabel yang diperkirakan dapat mempengaruhi hubungan tersebut salah satunya adalah good corporate governance.

Good corporate governance (GCG) merupakan suatu mekanisme yang mampu memberikan aturan dan kendali perusahaan guna menciptakan nilai tambah (Prabaningrat dan Widanaputra, 2015). Melalui GCG, diharapkan nilai perusahaan akan dinilai baik oleh investor (Susanti dkk, 2010). Penerapan GCG yang baik mampu menjadi penghambat tindakan manajemen laba, sehingga laporan keuangan perusahaan akan menggambarkan nilai perusahaan yang sebenarnya (Watson, 2003). Pernyataan ini didukung dengan agency theory yang menyatakan bahwa dengan tata kelola yang baik menjadikan perusahaan lebih transparan dan kontrol publik menjadi lebih kuat. Pada penelitian ini GCG diukur dengan menggunakan skor pemeringkatan corporate governance perception index (CGPI). Menurut Vajriyanti (2015) menyatakan bahwa CGPI adalah program riset dan pemeringkatan penerapan tata kelola perusahaan yang baik di Indonesia pada perusahaan publik yang diselenggarakan oleh The Indonesian Institute of Corporate Governance (IICG).

Penelitian ini akan dikhususkan industri perbankan yang terdaftar di Bursa Efek Indonesia (BEI) periode 2011 sampai 2016. Alasan pemilihan lokasi tersebut karena mengacu pada peraturan Otoritas Jasa Keuangan Nomor 55/POJK.03/2016 yang mewajibkan bank umum untuk menerapkan prinsip-prinsip tata kelola dalam 
setiap kegiatan usaha bank pada seluruh tingkatan atau jenjang organisasi. Selain itu juga Otoritas Jasa Keuangan (OJK) sebagai lembaga pengawas perbankan di Indonesia berkerjasama dengan International Finance Corporation (IFC) untuk meningkatkan kualitas penerapan tata kelola perusahaan di Indonesia, khususnya bergerak di sektor jasa keuangan. Menurut Muliaman D Hadad selaku Ketua Dewan Komisioner OJK, Indonesia perlu memiliki sistem keuangan yang baik secara fundamental agar mampu melindungi kepentingan konsumen dan anggota masyarakat (www.swa.co.id). Pada tahun 2018, OJK dan IFC juga melakukan kesepakaan kelanjutan kerjasama melalui penandatangan Nota Kesepahaman dalam pembuatan Roadmap Keuangan berkelanjutan dimana pada Fase II Roadmap tersebut difokuskan pada penguatan implementasi tata kelola oleh lembaga jasa keuangan (www.ojk.go.id.).

Berdasarkan ketidakkonsistenan hasil penelitian tersebut, maka peneliti ingin melakukan penelitian mengenai pengaruh kecukupan modal pada profitabilitas dengan memasukan variabel moderasi, yaitu good corporate governance. GCG digunakan sebagai variabel moderasi, karena penerapan tata kelola perusahaan yang baik diduga akan menjadi pendukung terkait dengan kecukupan modal perusahaan, sehingga laporan keuangan menunjukan peningkatan profitabilitasnya.

Struktur modal merupakan gambaran dari bentuk proporsi finansial perusahan yaitu antara modal yang dimiliki yang bersumber dari utang jangka panjang (long-term liabilities) dan modal sendiri (shareholder's equity) yang menjadi sumber pembiayaan suatu perusahaan (Fahmi, 2011:106). Struktur modal 
Ida Ayu Bintang Gesaputri dan A.A.G.P. Widanaputra. Pengaruh...

dapat diartikan lain sebagai gabungan sumber dana perusahaan yang bersumber dari utang jangka panjang dan modal sendiri yang digunakan sebagai sumber pembiayaan perusahaan.

Menurut Husnan (1998) perusahaan dalam membentuk struktur modal akan cendrung mengikuti pecking order theory. Teori struktur modal dengan pendekatan pecking order theory menjelaskan bahwa perusahaan akan menentukan hirarki dari sumber pendanaannya dimana pendanaan dari dalam perusahaan (internal financing) lebih dulu dari pada sumber pendanaan dari luar perusahaan (external financing). Teori ini bukan saja berlaku pada perusahaan non-keuangan tetapi juga berlaku terhadap industri perbankan (Marques dan Santos, 2003). Marques dan Santos (2003) mengatakan bahwa dalam proses pengambilan keputusan struktur modal yang terutama diperhatikan adalah tradeoff antara insentif dengan tata kelola (governance), serta struktur kepemilikan bank sebagai kontrol terhadap pengalokasian ekuitas dan utang (equity and debt).

Pengaruh kecukupan modal pada profitabilitas dapat dijelaskan dengan menggunakan teori struktur modal dengan menggunakan pendekatan pecking order theory. Penetepan struktur modal akan menggunakan kecukupan modal yang diperoleh pendanaan dari dalam perusahaan (internal financing) akan dipergunakan terlebih dahulu oleh perusahaan dan bila kebutuhan dana kurang maka dipergunakan dana eksternal sebagai tambahannya. Hal ini mengakibatkan struktur modal merupakan hal yang penting bagi perusahaan karena baik buruknya struktur modal akan mempunyai efek langsung terhadap posisi kinerja 
keuangan perusahaan dengan melihat kemampuan perusahaan untuk memperoleh laba (profitabilitas).

Profitabilitas merupakan kemampuan bank untuk menghasilkan atau memperoleh laba secara efektif dan efisien. Profitabilitas perusahaan perbankan menunjukan pendapatan yang mampu dihasilkan oleh perusahaan dalam satu atau setiap periode. Sebagian besar kinerja bank dapat dikatakan baik jika melihat dari tingginya profitabilitas, karena diasumsikan bahwa bank beroperasi dengan efektif dan efisien sehingga memungkinkan bank untuk memperluas usahannya.

Rachmawati (2013) menyatakan bahwa profitabilitas adalah alat ukur yang paling tepat untuk menilai kinerja suatu bank. Kemampuan bank untuk mendapatkan keuntungan akan berpatokan pada kinerja manajemen bank yang bersangkutan untuk mengelola total aset yang dimiliki oleh suatu perusahaan. Rasio profitabilitas merupakan salah satu ukuran dalam melihat kinerja keuangan perbankan. Berdasarkan pengertian tersebut, maka dapat disimpulkan bahwa profitabilitas adalah kemampuan suatu perusahaan dalam memperoleh laba (keuntungan) dalam periode tertentu.

Dalam penelilitian ini rasio profitabilitas diproksikan dengan rasio net interst magin (NIM). Menurut Hamadi dan Ali (2012) serta Plakalovic and Alihodzic (2015) rasio NIM sangat penting karena menunjukan efisiensi bank dalam melakukan fungsinya sebagai lembaga perantara dengan mengumpulkan dana serta mengalokasikan dana (pinjaman). NIM adalah rasio profitabilitas yang menunjukan kemampuan manajemen bank dalam mengelola aktiva produktifnya untuk menghasilkan pendapatan bunga bersih (Budiwati dan Jariah, 2012). 
Ida Ayu Bintang Gesaputri dan A.A.G.P. Widanaputra. Pengaruh...

Besaran rasio NIM akan memberikan sinyal terhadap seberapa efisiennya operasional kegiatan suatu bank (Hamadi dan Ali, 2012). NIM juga digunakan untuk mengukur kemampuan kinerja manajamen bank dalam menyalurkan kredit, mengingat pendapatan operasional bank sangat bergantung dari selisih antara suku bunga dari kredit yang disalurkan dengan suku bunga simpanan yang diterima (Rezha, 2014). Rasio NIM yang tinggi akan memberikan sinyal baik atau akan meningkatkan profitabilitas bank tersebut (Iloska, 2014).

Menurut surat Edaran Bank Indonesia Nomor 6/23/DPNP tanggal 31 Mei 2004 rasio NIM diukur dari perbandingan antara pendapatan bunga bersih terhadap aktiva produktif. Pendapatan bunga bersih diperoleh dari pendapatan bunga yang diterima dari pinjaman yang diberikan dikurangi dengan beban bunga dari sumber dana yang diberikan. Aktiva produktif merupakan aset operasional bank yang akan menghasilkan keuntungan atau laba bagi bank (Dennyza, 2015). Semakin tinggi rasio NIM menunjukan semakin tinggi efektifitas bank dalam pengelolaan aktiva produktifnnya, serta semakin besar rasio NIM maka akan meningkatkan pendapatan bunga atas aktiva produktif yang dikelola bank dengan baik sehingga dapat mengindikasi keadaan suatu bank dalam kondisi bermasalah semakin kecil.

Capital Adequacy Ratio (CAR) atau disebut rasio kecukupan modal, yaitu modal sebuah bank yang diperoleh dari dana sendiri (Luthfyanti,2017). Menurut Peraturan Bank Indonesia Nomor 14/18/PBI/2012 tentang Kewajiban Penyediaan Modal Minimum Bank Umum, bank wajib menyediakan modal minimum sebesar 8 persen dari aset tertimbang menurut risko (ATMR). Apabila bank akan 
mengadakan ekspansi atau perluasan pemberian kredit, maka harus memperhatikan jumlah modal yang dimiliki saat itu yang berarti apabila CARnya sudah mendekati ketentuan minimal, maka ekspansi kredit harus dibarengi dengan penambahan modal tersebut.

Teori keagenan adalah sebuah teori yang menggambarkan hubungan antara dua individu yang memiliki perbedaan kepentingan. Jensen dan Meckling (1976) menjelaskan hubungan keagenan di dalam teori agensi (agency theory) bahwa perusahaan merupakan kumpulan kontrak (nexus of contract) antara pemilik sumber daya ekonomis (principal) dan manajer (agent) yang mengurus penggunaan sumber daya tersebut. Dalam suatu hubungan keagenan terdapat suatu kontrak dimana principal memberikan perintah kepada agent atas nama principal, untuk melakukan suatu jasa dan memberi wewenang kepada agent dan memberikan keputusan terbaik bagi principal. Pemisahan yang terjadi antara kepemilikan dan pengelolaan perusahaan akan menimbulkan perbedaan kepentingan yang disebut dengan konflik keagenan atau agency conflict (Panda and Leepsa, 2017).

Teori agensi mendasarkan hubungan kontrak antara pemegang saham (principal) dan manajer (agent). Menurut Lubatkin (2007) teori agensi menggunakan tiga asumsi sifat manusia, yaitu: (1) manusia pada umumnya mementingkan diri sendiri (self interest), (2) manusia memiliki daya pikir terbatas mengenai persepsi masa mendatang (bounded rationality), dan (3) manusia selalu menghindari risiko (risk averse). Berdasarkan asumsi tersebut, manusia akan 
Ida Ayu Bintang Gesaputri dan A.A.G.P. Widanaputra. Pengaruh...

bertindakan opportunistic yaitu mengutamakan kepentingan pribadinya (Eisenhardt, 1989).

Konflik kepentingan antara agent dan principal dapat diminimalkan melalui beberapa cara antara lain pemberian insentif kepada agent atas tindakannya sesuai dengan kepentingan pemegang saham. Salah satu bentuk insentif yang dapat diterapkan adalah memberikan pihak agent kesempatan untuk menjadi principal atau pemegang saham, hal ini dikarenakan apabila pihak agent diberikan kesempatan menjadi pemegang saham maka kepentingan pihak agent akan sejalan dengan kepentingan principal. Scott (2011:53) menggambarkan program kompensasi eksekutif merupakan salah satu bentuk kontrak keagenan antara perusahaan dengan para agent nya sebagai usaha penyejajaran kepentingan yang dimiliki masing-masing pihak.

Pengaruh good corporate governance terhadap hubungan kecukupan modal pada profitabilitas dapat dijelaskan dengan menggunakan teori keagenan. Tata kelola perusahaan erat kaitannya dengan teori keagenan yang merupakan suatu hubungan kontraktual antara pihak principal dan agent. Dari hubungan kontraktual ini akan menimbulkan masalah baru karena masing-masing pihak ingin memaksimalkan utilitas (tingkat kepuasan individu) sehingga akan menimbulkan masalah keagenan (agency problem). Dalam upaya mengatasi atau mengurangi masalah keagenan (agency problem) ini menimbulkan biaya keagenan (agency cost) yang akan ditanggung baik oleh principal maupun agent. Dengan penerapan good corporate governance akan dapat meminimalkan masalah agency problem dan diharapkan kegiatan usaha akan berjalan sesuai 
dengan yang dinginkan dengan mengikuti prinsip-prinsip good corporate governance. Apabila dengan struktur modal dan tata kelola perusahaan yang baik itu sudah dimiliki, perusahaan akan mampu untuk memfokuskan perhatian untuk meningkatkan kemampuan memperoleh laba (profitabilitas) dalam kinerja keuangannya.

Good corporate governance (GCG) adalah seperangkat peraturan yang mengatur hubungan antara pemegang saham, pengelola perusahaan, pihak kreditur, pemerintah, karyawan, serta pemegang kepentingan internal dan eksternal lainnya yang berkaitan dengan hak-hak dan kewajiban mereka, sehingga menciptakan nilai tambah bagi semua pihak yang berkepentingan terhadap perusahaan (FCGI, 2001).

Menurut pedoman Komite Nasional Kebijakan Governance atau KNKG (2006) terdapat 5 (lima) asas Good corporate governance yang diperlukan untuk mencapai kesinambungan usaha (sustainability) perusahaan dengan memperhatikan pemangku kepentingan (stakeholders). Adapun kelima asas tersebut terdiri dari: 1) Keterbukaan (transparency). Untuk menjaga objektifitas dalam menjalankan bisnis, perusahaan harus menyediakan informasi yang material dan relavan dengan cara mudah diakses serta dapat dipahami oleh pemangku kepentingan. Perusahaan harus mengambil inisiatif untuk mengungkapkan tidak hanya masalah yang diisyaratkan oleh peraturan perundang-undangan, tetapi juga hal yang penting untuk pengambilan keputusan oleh pemegang saham, kreditur dan pemangku kepentingan lainnnya. 2) Akuntabilitas (accountability). Perusahaan harus dapat mempertanggungjawabkan 
Ida Ayu Bintang Gesaputri dan A.A.G.P. Widanaputra. Pengaruh...

kinerjanya secara transaparan dan wajar. Untuk itu perusahaan harus dikelola secara benar, terukur dan sesuai dengan kepentingan perusahaan dengan tetap memperhitungkan kepentingan pemegang saham dan pemangku kepentingan lainnya. 3) Pertanggungjawaban (responbility). Perusahaan harus mematuhi peraturan perundang-undangan serta melaksanakan tanggung jawab terhadap masyarakat dan lingkungan sehingga dapat terpelihara kesinambungan usaha dalam jangka panjang dan mendapat pengakuan sebagai good corporate citizen.

Selain Komite Nasional Kebijakan Governance (KNKG), salah satu lembaga independen yang berfokus pada penilaian dan melakukan riset pada penerapat konsep corporate governance (CG) di perusahaan Indonesia adalah Indonesia Institute of Corporate Governance (IICG). IICG merupakan salah satu lembaga independen yang melakukan pemeringkatan penerapa CG pada perusahaan-perusahaan di Indonesia melalui riset yang dirancang guna memacu perusahaan dalam peningkatan kualitas penerapan konsep CG. IICG juga berkejasama dengan Majalah SWA sebagai mitra media publikasi yag nantinya akan menghasilkan Corporate Governance Perception Index (Yudiastuti dan Wirasedana, 2018).

CGPI merupakan sebuah program yang didesain untuk melakukan pemeringkatan mengenai penerapan tata kelola perusahaan publik oleh IICG. Sejak tahun 2001 CGPI telah diikuti oleh perusahaan publik (emiten), Badan Usaha Milik Negara (BUMN), Badan Usaha Milik Daerah (BUMD), Perbankan dan Perusahaan Swasta (BUMS). Pemeringkatan CGPI dilakukan sebagai upaya dalam meningkatkan kualitas penerapan prinsip-prinsip GCG oleh perusahaan- 
perusahaan yang ada di Indonesia (Lestari, 2016). Melalui program ini IICG berusaha untuk meninjau sejauh mana perusahaan menerapkan GCG.

Penilaian IICG dilakukan dengan cara memberikan nilai skor kepada perusahaan peserta, besaran nilai skor ini dibuat berdasarkan acuan yang telah dibuat IICG. Skor ini diambil hasilnya berdasarkan hasil kuesioner penelitian yang berikan ke perusahaan peserta. Berikut bobot nilai yang digunakan untuk mengukur CGPI:

Tabel 3.

Bobot Penilaian CGPI

\begin{tabular}{ccc}
\hline No & Indikator & Bobot (\%) \\
\hline 1 & Selfassessment & 25 \\
2 & Kelengkapan dokumen & 23 \\
3 & Penyusunan makalah dan presentasi & 17 \\
4 & Obeservasi ke perusahaan & 35 \\
\hline
\end{tabular}

Sumber: Majalah SWA, 2018

Nilai CGPI dihitung berdasarkan jumlah nilai akhir yang didapatkan dari setiap proses diatas. Setelah nilai CGPI dari setiap perusahaan keluar maka selanjutnya nilai CGPI perusahaan secara keseluruhan akan dibahas di Forum Panel untuk menentukan pemeringkatan CGPI. Hasil penelitian CGPI akan dijadikan acuan untuk menentukan peringkat perusahaan yang memiiki skor tertinggi sampai terendah.

Penelitian ini menggunakan GCG sebagai pemoderasi pengaruh kecukupan modal terhadap profitabilitas. Pengelolaan perusahaan berdasarkan prinsip good corporate governance (GCG) merupakan upaya menjadikan GCG sebagai pedoman bagi pengelolaan perusahaan dalam mengelola manajemen. Penerapan prinsip-prinsip GCG saat ini sangat diperlukan agar perusahaan dapat bertahan dalam menghadapi persaingan yang semakin ketat dan dapat menerapkan etika 
Ida Ayu Bintang Gesaputri dan A.A.G.P. Widanaputra. Pengaruh...

bisnis secara konsisten, sehingga mewujudkan iklim usaha yang sehat, efisien, dan transparan. Dalam kaitannya dengan kinerja keuangan, laporan keuangan menjadi patokan untuk mengukur bagaimana kinerja suatu perusahaan. Melalui penerapan GCG akan membantu perusahaan untuk terciptanya kinerja keuangan yang baik. Ketika perusahaan memiliki ketersediaan modal yang cukup tinggi untuk menjalankan kegiatan usahanya dengan didukung penerapan GCG yang baik, kemampuan perusahaan dalam memperoleh laba akan meningkat.

Berdasarkan uraian di atas, berikut hipotesis yang peneliti kembangkan sebagai berikut.

$\mathrm{H}_{1}$ : Semakin tinggi kecukupan modal, maka semakin tinggi kinerja keuangan perusahaan terutama bagi perusahaan yang semakin tinggi indeks GCGnya.

\section{METODE PENELITIAN}

Lokasi penelitian dilakukan pada perusahaan perbankan terdaftar di BEI tahun 2011-2016 yang dimana data tersebut diperoleh dengan mengakses situs www.idx.co.id. Obyek dalam penelitian ini adalah pengaruh kecukupan modal pada profitabilitas dengan good corporate governance sebagai variabel pemoderasi di perusahaan perbankan yang terdaftar di BEI tahun 2011-2016.

Populasi dalam penelitian ini adalah seluruh perusahaan perbankan yang terdaftar di BEI tahun 2011-2016, yaitu sebanyak 11 perusahaan. Metode penentuan sampel dalam penelitian ini menggunakan metode nonprobability sampling dengan teknik purposive sampling. Teknik analisis data yang digunakan dalam penelitian ini adalah moderated regression analysis dengan menggunakan program SPSS. Moderated Regression Analysis bertujuan untuk mengetahui peran 
suatu variabel yang dapat memperkuat atau memperlemah korelasi antara suatu variabel bebas (independen) terhadap variabel terikat (dependen). MRA merupakan aplikasi khusus dalam analisis regresi linier berganda di mana dalam persamaan regresinya mengandung unsur interaksi (perkalian dua atau lebih variabel independen) dengan rumus persamaan berikut.

$$
Y=\alpha+\beta_{1} X_{1}+\beta_{2} X_{2}+\beta_{3} X_{1} * X_{2}+\varepsilon
$$

Keterangan:

$\begin{array}{lll}\mathrm{Y} & : & \text { Profitabilitas } \\ \mathrm{A} & : & \text { Konstanta } \\ \mathrm{X}_{1} & : & \text { Kecukupan Modal } \\ \mathrm{X}_{2} & : & \text { Good Corporate Governance (GCG) } \\ \mathrm{X}_{1} * \mathrm{X}_{2} & : & \text { Interaksi antara kecukupan modal dengan GCG } \\ \beta_{1-} \beta_{3} & : & \text { Koefisien Regresi } \\ \mathrm{e} & : & \text { Variabel pengganggu }\end{array}$

dari hasil analisis yang dilakukan dapat diamati mengenai koefisien determinasi (adjusted $R^{2}$ ), uji kelayakan model (uji F), dan uji hipotesis (uji t).

\section{HASIL DAN PEMBAHASAN}

Statistik deskriptif memberikan gambaran umum tentang objek penelitian yang dijadikan sampel. Statistik deskriptif dalam penelitian ini disajikan untuk menjelaskan karateristik sampel terutama mencakup nilai minimum, maksimum, mean, dan standar deviasi dari masing-masing variabel. Hasil dari statistik deskriptif tersebut dapat dilihat pada tabel 4. berikut. 
Tabel 4.

Hasil Statistik Deskriptif

\begin{tabular}{|c|c|c|c|c|c|}
\hline & $\mathbf{N}$ & Minimum & Maximum & Mean & Std. Deviation \\
\hline NIM & 42 & 1,64 & 8,55 & 5,7983 & 1,38095 \\
\hline CAR & 42 & 9,41 & 22,91 & 16,9064 & 2,5987 \\
\hline GCG & 42 & 78,85 & 93,3 & 86,7598 & 3,3022 \\
\hline $\begin{array}{l}\text { Valid } N \\
\text { (listwise) }\end{array}$ & 42 & & & & \\
\hline
\end{tabular}

Sumber: Data diolah, 2018

Berdasarkan Tabel 4 dapat disimpulkan bahwa jumlah pengamatan (N) penelitian ini berjumlah 42. Nilai terendah dari data ditunjukkan oleh skor minimum, sedangkan nilai tertinggi dari data ditunjukkan oleh skor maksimum dalam tabel. Mean digunakan untuk mengukur nilai rata-rata dari data, dan standar deviasi menunjukkan simpangan baku.

Nilai terendah (minimum) variabel NIM adalah 1,64, sedangkan nilai tertinggi (maksimum) sebesar 8,55. Nilai rata-rata pada variabel NIM sebesar 5,7983. Deviasi standar variabel NIM sebesar 1,38095 hal ini menunjukan bahwa standar penyimpangan data terhadap nilai rata-ratanya sebesar 1,38095 .

Nilai terendah (minimum) variabel CAR adalah 9,41, sedangkan nilai tertinggi (maksimum) sebesar 22,91. Nilai rata-rata pada variabel CAR sebesar 16,9064. Deviasi standar variabel CAR sebesar 2,5987 hal ini menunjukan bahwa standar penyimpangan data terhadap nilai rata-ratanya sebesar 2,5987. Nilai terendah (minimum) variabel GCG adalah 77,8, sedangkan nilai tertinggi (maksimum) sebesar 93,3. Nilai rata-rata pada variabel GCG sebesar 86,7598. Deviasi standar variabel GCG sebesar 3,3022 hal ini menunjukan bahwa standar penyimpangan data terhadap nilai rata-ratanya sebesar 3,3022.

Hasil uji normalitas dari penelitian ini disajikan dalam tabel 5 berikut. 
Tabel 5.

Hasil Uji Normalitas

\begin{tabular}{|c|c|c|}
\hline \multirow{2}{*}{$\mathrm{N}$} & \multicolumn{2}{|c|}{ Unstandardized Residual } \\
\hline & & 42 \\
\hline \multirow{3}{*}{ Normal Parameters ${ }^{a, b}$} & Mean & 0 \\
\hline & Std. Deviation & 1,12010519 \\
\hline & Absolute & 0,124 \\
\hline \multirow[t]{2}{*}{ Most Extreme Differences } & Positive & 0,124 \\
\hline & Negative & $-0,118$ \\
\hline Test Statistic & & 0,124 \\
\hline Asymp. Sig. (2-tailed) & &, $106^{\mathrm{c}}$ \\
\hline
\end{tabular}

Data penelitian yang digunakan dikatakan berdistribusi normal apabila nilai Asymp. Sig. (2-tailed) lebih besar dari $\alpha=0,05$. Berdasarkan Tabel 5 di atas, nilai Asymp. Sig. (2-tailed) dari model persamaan yang diuji sebesar 0,106 lebih besar dari 0,05 . Hal ini menunjukkan data yang digunakan dalam penelitian ini telah berdistribusi normal.

Adapun hasil pengujian autokorelasi dari penelitian ini disajikan pada Tabel 6 berikut.

Tabel 6.

Hasil Uji Autokorelasi

\begin{tabular}{|c|c|c|c|c|c|}
\hline Model & $\mathbf{R}$ & R Square & $\begin{array}{l}\text { Adjusted } R \\
\text { Square }\end{array}$ & $\begin{array}{c}\text { Std. Error of the } \\
\text { Estimate }\end{array}$ & $\begin{array}{l}\text { Durbin- } \\
\text { Watson }\end{array}$ \\
\hline 1 &, $585^{\mathrm{a}}$ & 0,342 & 0,29 & 1,16348 & 2,031 \\
\hline
\end{tabular}

Sumber: Data diolah, 2018

Berdasarkan hasil uji autokorelasi pada Tabel 6 di atas, nilai dw yang dihasilkan sebesar 2,031. Oleh karena jumlah $\mathrm{n}=42$ dan $\mathrm{k}=2$, diperoleh nilai $\mathrm{d}_{\mathrm{L}}$ $=1,4073$ dan $d_{u}=1,6061$ sehingga diperoleh juga nilai $4-d_{u}=2,3939$, maka dapat dirumuskan kriteria $\mathrm{d}_{\mathrm{u}}<\mathrm{dw}<4-\mathrm{d}_{\mathrm{u}}$ yaitu $(1,4073<2,031<2,3939)$, maka dapat disimpulkan bahwa tidak terjadi gejala autokorelasi.

Adapun hasil pengujian heteroskedastisitas disajikan pada Tabel 4.6 berikut. 
Tabel 7.

Hasil Uji Heterokedastisitas

\begin{tabular}{|c|c|c|c|c|c|c|}
\hline \multirow[t]{2}{*}{ Model } & & \multicolumn{2}{|c|}{$\begin{array}{c}\text { Unstandardized } \\
\text { Coefficients }\end{array}$} & \multirow{2}{*}{$\begin{array}{c}\text { Standardized } \\
\text { Coefficients } \\
\text { Beta }\end{array}$} & \multirow[t]{2}{*}{$\mathbf{t}$} & \multirow[t]{2}{*}{ Sig. } \\
\hline & & B & Std. Error & & & \\
\hline \multirow{4}{*}{1} & (Constant) & $-8,577$ & 14,929 & & $-0,575$ & 0,569 \\
\hline & CAR & 1 & 0,941 & 3,363 & 1,062 & 0,295 \\
\hline & GCG & 0,088 & 0,174 & 0,378 & 0,508 & 0,614 \\
\hline & $\mathrm{CAR} * \mathrm{GCG}$ & $-0,01$ & 0,011 & $-3,3$ & $-0,949$ & 0,349 \\
\hline
\end{tabular}

Sumber: Data diolah, 2018

Berdasarkan Tabel 7 dapat dilihat bahwa nilai Sig. dari variabel CAR, GCG, dan variabel interaksi masing-masing sebesar 0,$295 ; 0,614 ; 0,349$. Nilai tersebut lebih besar dari 0,05 yang berarti tidak terdapat pengaruh antara variabel bebas terhadap absolute residual. Dengan demikian, model yang dibuat tidak mengandung gejala heteroskedastisitas.

Hasil pengujian disajikan dalam rekapitulasi hasil analisis regresi linear berganda dengan menggunakan uji interaksi pada tabel 8 berikut.

Tabel 8.

Rekapitulasi Hasil MRA

\begin{tabular}{|c|c|c|c|c|c|c|}
\hline \multirow{2}{*}{ Model } & & \multicolumn{2}{|c|}{$\begin{array}{c}\text { Unstandardized } \\
\text { Coefficients }\end{array}$} & \multirow{2}{*}{$\begin{array}{c}\text { Standardized } \\
\text { Coefficients } \\
\text { Beta }\end{array}$} & \multirow{2}{*}{$\mathbf{t}$} & \multirow{2}{*}{ Sig. } \\
\hline & & B & $\begin{array}{l}\text { Std. } \\
\text { Error }\end{array}$ & & & \\
\hline \multirow{7}{*}{1} & (Constant) & $-46,887$ & 23,788 & & $-1,971$ & 0,056 \\
\hline & CAR & 3,138 & 1,499 & 5,905 & 2,093 & 0,043 \\
\hline & GCG & 0,561 & 0,277 & 1,342 & 2,026 & 0,05 \\
\hline & $\mathrm{CAR} * \mathrm{GCG}$ & $-0,033$ & 0,017 & $-5,962$ & $-1,923$ & 0,062 \\
\hline & Adjusted $R^{2}$ & 0,29 & & & & \\
\hline & F hitung & 6,586 & & & & \\
\hline & Sig. F &, $001^{\mathrm{b}}$ & & & & \\
\hline
\end{tabular}

Sumber: Data diolah, 2018

Berdasarkan hasil analisis uji interakasi (MRA) yang ditunjukkan pada Tabel 8 maka disusun persamaan regresi sebagai berikut.

$$
Y=-46,887+3,138 X_{1}+0,561 X_{2}-0,033 X_{1} * X_{2}
$$


Nilai konstanta $-46,887$ menunjukan bahwa bila variabel CAR dan GCG sama dengan nol, maka variabel NIM akan bernilai sebesar -46,887. Nilai koefisien regresi CAR sebesar 3,138 menunjukan bahwa bila CAR naik satu satuan, maka NIM akan mengalami peningkatan sebesar 3,138 satuan dengan asumsi variabel lainnya konstan. Nilai koefisien regresi GCG sebesar 0,561 menunjukan bahwa bila GCG naik satu satuan, maka NIM akan mengalami peningkatan sebesar 0,561 satuan dengan asumsi variabel lainnya konstan.

Nilai koefisien regresi CAR.GCG sebesar -0,033 menunjukan bahwa bila interaksi antara CAR dengan GCG naik satu satuan, maka NIM akan mengalami penurunan sebesar 0,033 satuan dengan asumsi variabel lainnya konstan.

Penjelasan lainnya mengenai persamaan di atas dapat diketahui bahwa jika nilai konstanta $(\alpha)$ menunjukkan nilai negatif maka memiliki arti jika variabel CAR, GCG, serta moderat $\mathrm{X}_{1} \cdot \mathrm{X}_{2}$ (interaksi antara CAR dengan GCG) dinyatakan konstan pada angka 0, maka nilai NIM akan menurun. Berdasarkan persamaan tersebut terlihat bahwa terdapat pengaruh positif variabel CAR $\left(\mathrm{X}_{1}\right)$ dan GCG $\left(\mathrm{X}_{2}\right)$ pada NIM (Y). Sedangkan interaksi antara CAR dengan GCG (moderat $\mathrm{X}_{1} \cdot \mathrm{X}_{2}$ ) memiliki pengaruh negatif pada NIM (Y).

Analisis regresi linear berganda dengan metode interaksi (MRA) mengamati goodness of fit (uji kecocokan) dengan melihat koefisien determinasi $\left(\mathrm{R}^{2}\right)$, uji kelayakan model (uji F) dan uji hipotesis (uji t).

Uji kelayakan model (Uji F) bertujuan untuk menguji apakah model yang digunakan dalam penelitian ini layak atau tidak untuk digunakan sebagai alat analisis dalam menguji pengaruh variabel independen pada variabel dependennya. 
Adapun hasil dari pengujian kesesuaian model dalam penelitian ini telah disajikan pada Tabel 9 berikut.

Tabel 9.

Hasil Uji Kelayakan Model (F)

\begin{tabular}{rlrrrrr}
\hline \multirow{2}{*}{ Model } & & $\begin{array}{c}\text { Sum of } \\
\text { Squares }\end{array}$ & df & $\begin{array}{c}\text { Mean } \\
\text { Square }\end{array}$ & \multicolumn{1}{c}{ F } & \multirow{2}{*}{ Sig. } \\
\hline \multirow{2}{*}{1} & Regression & 26,748 & 3 & 8,916 & 6,586 &, $001^{\text {b }}$ \\
1 & Residual & 51,44 & 38 & 1,354 & & \\
& Total & 78,188 & 41 & & & \\
\hline
\end{tabular}

Sumber: Data diolah, 2018

Berdasarkan hasil uji kesesuaian model pada Tabel 9 di atas, dapat dilihat bahwa nilai dari uji F sebesar 6,586 dan nilai $p$-value (Sig. F) yakni 0,001 lebih kecil dari nilai $\alpha=0,05$. Hal ini menunjukkan bahwa model persamaan dalam penelitian ini layak untuk digunakan.

Analisis koefisien determinasi digunakan untuk mengukur seberapa jauh kemampuan semua variabel bebas dalam menerangkan variasi dari variabel dependennya (Ghozali, 2016:95). Dalam penelitian ini koefisien determinasi dilihat melalui nilai adjusted $R$ square. Adapun nilai dari nilai adjusted $R$ square pada penelitian ini telah disajikan pada Tabel 10 berikut.

Tabel 10.

Koefisien Determinasi

\begin{tabular}{|c|c|c|c|c|c|}
\hline Model & & $\mathbf{R}$ & R Square & Adjusted R Square & $\begin{array}{c}\text { Std. Error of the } \\
\text { Estimate }\end{array}$ \\
\hline & 1 & $.585^{\mathrm{a}}$ & 0,342 & 0,29 & 1,16348 \\
\hline
\end{tabular}

Sumber: Data diolah, 2018

Berdasarkan pada Tabel 10 diatas, dapat dilihat bahwa nilai dari adjusted $R$ square sebesar 0,29 dimana memiliki arti bahwa 29\% variasi perubahan NIM dapat dijelaskan oleh CAR dan GCG. Sedangkan sisanya sebesar $71 \%$ dipengaruhi oleh variabel lain diluar dari model regresi yang digunakan. 
Uji statistik $\mathrm{t}$ dilakukan untuk mengetahui seberapa besar pengaruh variabel independen terhadap variabel dependen secara parsial. Uji statistik $t$ dilakukan dengan membandingkan hasil nilai signifikansi dengan $\alpha=0,05$ dan dapat dijelaskan sebagai berikut.

Hasil pengujian pengaruh kecukupan modal terhadap profitabillitas dengan good corporate governance sebagai variabel pemoderasi, berdasarkan hasil perhitungan diketahui bahwa nilai signifikansi $\mathrm{t}=0,062>$ alpha $=0,05$. Hal ini berarti hipotesis penelitian ditolak, dimana variabel GCG bukan sebagai pemoderasi pengaaruh kecukupan modal pada profitabilitas.

Hipotesis $\left(\mathrm{H}_{1}\right)$ yang dikemukakan dalam penelitian adalah semakin tinggi kecukupan modal, maka semakin tinggi kinerja keuangan perusahaan terutama bagi perusahaan yang semakin tinggi indeks GCG-nya. Berdasarkan hasil uji hipotesis, menunjukan hasil koefisien regresi -0,033 dengan siginifikansi 0,062 > alpha $=0,05$, yang artinya good corporate governance bukan sebagai pemoderasi pengaruh kecukupan modal terhadap profitabilitas, sehingga hipotesis ditolak. Hal ini mungkin disebabkan oleh karena indeks GCG yang tinggi tidak menjamin profitabilitas yang diterima perusahaan akan tinggi begitu juga sebaliknya.

Menurut Wasiuzzaman (2013), profitabilitas yanng diproksikan dengan NIM mengkhususkan kaitannya dengan seberapa menguntungkannya perusahaan perbankan dalam kegiatan penyaluran dana kredit dengan menunjukan pendapatan pinjaman rasio sebagai rasio. Secara teoritis, pelaksanaan GCG dapat meningkatkan nilai perusahaan dengan meningkatkan kinerja keuangan. Dalam konteks pengaruh pelaksanaan GCG terhadap kinerja keuangan perusahaan 
Ida Ayu Bintang Gesaputri dan A.A.G.P. Widanaputra. Pengaruh...

sesungguhnya faktor-faktor internal dan eksternal lain yang secara teoritis diduga turut memengaruhi diantaranya: beban modal pinjaman, tingkat pajak pemerintah atas laba usaha, tingkat produktivitas aset, efektivitas penempatan ekuitas dan biaya operasional.

Dilihat dari jangka waktunya penerapan GCG lebih bersifat jangka panjang sehingga tidak dapat diukur kesuksesannya jika hanya mengandalkan satu periode akuntansi saja sedangkan perhitungan profitabilitas lebih bersifat jangka pendek, dimana hasil yang dicapai dari periode tersebut merupakan hasil tambah perusahaan yang berdiri sendiri (Melvina dan Restuti, 2012). Oleh karena itu, ketika perusahaan memiliki kecukupan modal yang tinggi dengan didukung dengan indeks GCG yang tinggi pula, belum tentu perusahaan tersebut akan mendapatkan profitibilitas yang meningkat, karena pencapaian peningkatan kinerja keuangan dalam meningkatkan keuntungan perusahaan dapat disebabkan oleh beberapa faktor lain yang lebih dominan sehingga menyebabkan indeks GCG tidak dapat memengaruhi pencapaian laba di perusahaan tersebut.

Penelitian ini memberikan tambahan informasi mengenai pengaruh kecukupan modal terhadap profitabilitas dengan good corporate governance sebagai variabel pemoderasi di perusahaan perbankaan pada tahun 2011-2016. Penelitian ini juga diharapkan akan memberikan kontribusi positif bagi semua pihak khususnya pihak investor dan perusahaan. Penelitian selanjutnya diharapkan dapat mempertimbangkan variabel-variabel lain seperti ukuran perusahaan, belanja operasional terhadap pendapatan operasional, non 
performing loan, loan to deposit ratio, yang diduga berpengaruh pada hubungan antara kecukupan modal, good corporate governance dengan profitabilitas.

Penelitian ini memberikan implikasi bagi investor sebagai pertimbangan dan pengetahuan mengenai profitabilitas serta faktor-faktor yang memengaruhinya alam menjalankan kegiatan opersional perusahaan. Hasil penelitian ini juga diharapkan dapat membantu perusahaan dalam mempertimbangkan pengambilan keputusan keuangan perusahaan karena keputusan keuangan yang diambil akan memengaruhi kelangsungan hidup perusahaan dan preferensi investor terhadap prospek perusahaan di masa mendatang. Perusahaan harus memiliki strategi bagaimana menghadapi berbagai faktor eksternal yang mungkin dapat menghambat kelangsungan hidup perusahaan.

\section{SIMPULAN}

Berdasarkan hasil penelitian mengenai pengaruh kecukupan modal terhadap profitabilitas dengan GCG sebagai variabel pemoderasi, dapat disimpulkan bahwa variabel GCG bukan sebagai pemoderasi pengaruh kecukupan modal terhadap profitabilitas. Hal ini mungkin disebabkan oleh karena GCG yang tinggi tidak menjamin tingkat kinerja keuangan perusahaan akan tinggi begitu juga sebaliknya.

Berdasarkan hasil dan pembahasan serta simpulan pada penelitian ini, adapun saran-saran yang dapat diberikan dalam penelitian ini, yaitu peneliti selanjutnya diharapkan menggunakan variabel serta proksi lain. Para investor dan calon investor diharapkan mampu menyimak laporan keuangan tahunan yang 
Ida Ayu Bintang Gesaputri dan A.A.G.P. Widanaputra. Pengaruh...

dipublikasikan di BEI agar dapat mengambil keputusan secara benar dalam berinvestasi di suatu perusahaan.

\section{REFERENSI}

Anggreni, Made Ria \& I Made Sadha Suardhika. (2014). Pengaruh Dana Pihak Ketiga, Kecukupan Modal, Risiko Kredit dan Suku Bunga pada Profitabilitas. E-Jurnal Akuntansi Universitas Udayana,9 (1), hal. 27-38.

Agustiningrum, R. (2013). Analisis Pengaruh CAR, NPL, dan LDR terhadap Porfitabilitas pada Perusahaan Perbankan. Jurnal Bisnis dan Ekonomi, 2 (8), 885-902.

Ariff, Ahmad and M.J. Skully. (2008). The determinants of Bank Capital Ratio in as Developing Asia-Pacific Financial Market, 15 (4), 255-272.

Bank Indonesia. (2012). Statistik Perbankan Indonesia 2011. Jakarta: Direktorat Perizinan dan Infromasi Perbankan Bank Indonesia.

Bank Indonesia. (2013). Statistik Perbankan Indonesia 2012. Jakarta: Direktorat Perizinan dan Infromasi Perbankan Bank Indonesia.

Brock, P \& L.Suarez. (2000). Understanding the Behavior of Bank Spreads in Latin America. Journal od Development Economics, 63 (1), 113-134.

Budiwati, Hesti \& Ainun Jariah. (2012). Analisis Non Performing Assets dan Loan to Deposits Ratio serta pengaruhnya terhadap Net Interest Margin sebagai indikator Spread Based pada Bank Umum Swasta Nasional di Indonesia Periode 20014-2007. Jurnal WIGA, 2 (2), hal.90-102.

Dumicic Mirna \& Ridzak Tomislav. (2013). Determinants of Banks Net Interest Margin in Central and Eastern Europe. Journal Financial Theory and Practice, 37 (2), 243-255.

Dennyza, Satriawan Reza. (2015). Pengaruh Dana Pihak Ketiga dan Kredit yang Disalurkan Terhadap Net Interest Margin Pada PT Bank Rakyat Indonesia (PERSERO), Tbk. Jurna JIBEKA, 9(1), hal.70-75.

Fahmi, Irham. (2011). Analisis Laporan Keuangan. Bandung: Alfabeta.

Forum for Corporate Governance in Indonesia (FCGI). 2001. Corporate Governance (Tata Kelola Perusahaan).http:/fcgi.or.id. Diakses $26 \mathrm{Mei}$ 2018. 
Ghozali, Imam. (2016). Aplikasi Analisis Multivariate Dengan Program IBM SPSS 23. Semarang: Badan Penerbit Universitas Diponogoro

Govindarajan, V. (1986). Impact of Participation in the Budgetary Process on Managerial Attitude and Performance Universalitic and Contigency Perspective. Decision Science, 17(4), 496-516.

Hamadi, Hassan \& Ali Awdeh. (2012). The Determinants of Bank Net Interest Margin: Evidence from the Lebanese Banking Sector. Journal of Money, Investment and Banking, 23, 85-98.

Husnan, S. (1996). Manajemen Keuangan Teori dan Penerapan 9 Keputusan Jangka Panjang. Yogyakarta: BPFE.

Iloska, Nadica. (2014). Determinants of Net Interest Margins - The Case of Macedonia. Journal of Applied Economics and Business, 2 (2), pp:17-36.

Jensen, M.C \& W.H. Meckling. (1986). Theory of The Firm: Managerial Behavior, Agency Costs and Ownership Structure. Journal of Financial Economics, 3 (4), 305-360.

Komite Nasional Kebijakan Governance (KNKG). (2006). Pedoman Umum Good Corporate Governance Indonesia.http://knkg-indonesia.com. Diakses 26 Mei 2017.

Lestari, Sri Dewi \& Ni Gusti Putu Wirawati. (2016). Good Corporate Governance sebagai Pemoderasi Pengaruh Asimetri Informasi pada Manajemen Laba. E-Jurnal Akuntansi Universitas Udayana, 16 (1), hal. 156-182.

Lubatkin, Michael. (2007). One More Time: What is a Realistic Theory of Corporate Governance. Journal of Organizational Behaviour, 28 (2), pp. 59-67.

Luthfyanti, Kiki Fajrina. (2017). Analisis Faktor Penentu Kredit Bermaslaah Pada Kredit Usaha Rakyat (Studi Kasus Pada KUR Bank Bukopin dan Bank Syariah Mandiri) Periode Januari 2012-November 2014. Jurnal Ilmiah Mahasiswa Fakultas Ekonomi dan Bisnis Universitas Brawijaya, 5(2).

Leykun, F. (2016). Factors Affecting the Net Interest Margin of Commercial Bank of Ethiopia. International Journal of Scientific and Research Publication,. 6 (6), pp. 150-161.

Majalah SWA. (2012). Bobot Dalam Empat Tahapan CGPI.https://swa.co.id. Diakses 27 Mei 2018. 
Ida Ayu Bintang Gesaputri dan A.A.G.P. Widanaputra. Pengaruh...

Margaret, Kamaliah, \& Poppy Nurmayanti. (2014). Faktor-Faktor yang Mempengaruhi Net Interest Margin (Bank Go Publik Tahun 2008 s/d 2011). Jurnal Tepak Manajemen Bisnis, 6 (3), hal. 69-80.

Marinkovic Srdan \& Radovic Ognjen. (2014). Bank Net Interest Margin Related to Risk, Ownership and Size: An Exploratory Study of The Serbian Banking Industri. Journal of Economic Researxg-Ekonomska Istrazivanja, 27 (1), pp. 134-154.

Marques, Manuel O. \& Mario C. Santos. (2003). Capital Structure Policy and Determinants: Evidence from the Portuguese Banking Industry, November 2003.

McShane, R,W \& I.G. Sharpe. (1985). A Time Series-Cross Sectio Analysis of Determinats of Australian Trading Bank Loan-Deposit Interest Margin: 1962-1981. Journal of Banking and Finance, 9 (1), pp. 155-136.

Melvina dan MI Mitha Dwi Restuti. (2012). Pengaruh Penerapan Good Corporate Governance Terhadap Kinerja Perusahaan yang Terdaftar di Bursa Efek Indonesia. Jurnal UNISSULA, 1 (1), 685-695.

Muchtar., Bustari., Rose Ramidani., \& Menik Kurnia Siwi. (2016). Bank dan Lembaga Keuangan Lain. Jakarta: KENCANA.

Nasserina, A. Ddk. (2015). Key Determinants of German Banking Sector Performance. Pertanika J.Soc. Sci \& Hum, 23 (2), pp.167-186.

Norris, Era Dabla \& Hogler Floerkemeier. (2007). Bank Efficiency and Market Structure: What Determines Banking Spreads in Armenia?. Working Paper, International Monetary Fund, WP/07/134.

Otoritas Jasa Keuangan. (2014). Statistik Perbankan Indonesia 2013. Jakarta: DepartemenPerizinan dan Infromasi Perbankan Otoritas Jasa Keuangan.

Otoritas Jasa Keuangan. (2015). Statistik Perbankan Indonesia 2014. Jakarta: DepartemenPerizinan dan Infromasi Perbankan Otoritas Jasa Keuangan.

Otoritas Jasa Keuangan. (2016). Statistik Perbankan Indonesia 2015. Jakarta: DepartemenPerizinan dan Infromasi Perbankan Otoritas Jasa Keuangan.

Otoritas Jasa Keuangan. (2017). Statistik Perbankan Indonesia 2016. Jakarta: DepartemenPerizinan dan Infromasi Perbankan Otoritas Jasa Keuangan.

Otoritas Jasa Keuangan. (2018). Siaran Pers: OJK dan IFC Sepakat Teruskan Kerjasama Pengmbangan Program Keuangan Berkelanjutan. https://www.ojk.go.id/id/berita-dan-kegiatan/siaran-pers/Pages/Siaran- 
Pers-OJK-Dan-IFC-Sepakat-Teruskan-Kerjasama-PengembanganProgram-Keuangan-Berkelanjutan.aspx. Diakses 27 Mei 2018.

Panda, Brahmadev and N.M.Leepsa. 2017. Agency Theory: Review of Theory and Evidence on Problems and Perspenctives. Indian Journal of Corporate Governance, 10 (1), pp. 74-95.

Peraturan Bank Indonesia Nomor 7/2/PBI/2005 Penilaian Kualitas Aktiva Bank Umum. 20 Januari 2005. Lembaran Negara Republik Indonesia Tahun 2005 Nomor 12 DPNP.

Peraturan Bank Indonesia Nomor 14/18/PBI/2012 tentang Kewajiban Penyediaan Modal Minimum Bank Umum. 28 November 2012. Lembaran Negara Republik Indonesia Tahun 2012 Nomor 261 DPNP.

Peraturan Otoritas Jasa Keuangan Nomor 55/POJK.03/2016 Penerapan Tata Kelola Bagi Bank Umum. 9 Desembar 2016. Lembaran Negara Republik Indonesia Tahun 2016 Nomor 286.

Plakalovic Novo, and Alihodzic Almir. 2015. Determinants of the Net Interest Margins in BH Banks. Journal of Industrija, 43 (1), pp: 133-53.

Prabaningrat, I.G.A.A dan A.A.G.P. Widanaputura. 2015. Pengaruh Good Corporate Governance dan Konservatisme Akuntansi pada Manajemen Laba. E-Jurnal Akuntansi Universitas Udayana, 10 (2), hal. 663-676.

Rachmawati, Mega Fitrah. 2013. Analisis Pengaruh Pertumbuhan Dana Pihak Ketiga, Loan to Deposit Ratio, Non Performing Loan, Biaya Operasional dan Net Interest Margin terhadap Profitabilitas Bank (Studi pada Bank Umum yang terdaftar di Bursa Efek Indonesia Periode 2010-2012). Jurnal Ilmiah Mahasiswa FEB Universitas Brawijaya, 2 (1), hal. 1-13.

Raharjo, Pamuji Gesang, Hakim Dedi Budiman, Manurung Adler Hayman, dan Maulana Tubagus N.A. 2014. The Determinant of Commercial Bank Interest Margin in Indonesia: An Analysis od Fixed Effecr Panel Regression. International Journal of Economics and Financial Issues, 4 (2), pp.295-308.

Rahim, Benny Nurzikri. 2014. Pengaruh Rasio Kecukupal Modal (Capital Adequacy Ratio) yang Memperhitungkan Risiko Kredit dan Risiko Pasar terhadap Profitabilitas, Fungsi Intermediasi dan Risiko Perbankan. Jurnal Sosial Ekonomi Pembangunan, 4 (1), hal. 245-262.

Rezha, Metasari Dwihilda. 2014. Pengaruh Capital Adequacy Ratio, Non Perfomring Loan, Loan to Deposit Ratio, Net Interest Margin, dan BOPO Terhadap Tingkat Profitabilitas Bank (Studi pada Bank Umum yang 
Ida Ayu Bintang Gesaputri dan A.A.G.P. Widanaputra. Pengaruh...

Terdaftar di Bursa Efek Indonesia). Jurnal Ilmiah Mahasiswa FEB, 2 (2), hal. 1-18.

Riyadi, Slamet. 2006. Banking Assets and Liability Management Edisi 3. Jakarta: FE UI.

Scott, W.R. 2011. Financial Accounting Theory, Sixth Edition. Canada: Pearson Prentice Hall.

Susanti, A.N., dkk. 2010. Analisis Pengaruh Mekanisme Corporate Governance terhadap Nilai Perusahaan dengan Kualitas Laba sebagai Intervening pada Perusahaan Manufaktur yang terdaftar di Bursa Efek Indonesia tahun 2004-2007. Simposium Nasional Keuangan 1 Sol, 2010.

Wangi, L.A.Loranita Gladys dan I Wayan Ramantha. 2017. Non Performing Loan Sebagai Pemoderasi Pengaruh KUR Pada Profitabilitas PT BRI (PERSERO) Tbk Cabang Denpasar. E-Jurnal Akuntansi Universitas Udayana, 20 (1), hal.320-351.

Wasiuzzaman, S. 2013. Comparative Study of The Performance of Islamic and Conventional Bank: The Case of Malaysia. Homanomic,. 29(1), pp.4360 .

Watson, G.H. 2003. Corporate Governance:Quality at the Top. Annual Quality Proceedings, 5 (7), pp. 123-137.

Yudiastuti, Luh Nopia dan I Wayan Pradnyantha Wirasedana. 2018. Good Corporate Governance Memoderasi Pengaruh Leverage Terhadap Manajemen Laba. E-Jurnal Akuntansi Universitas Udayana, 23 (1), hal. 130-155. 